ISSN 1991- 8690

الترقيم الدولي 8690 - 2091

Website: http://jsci.utq.edu.iq

Email: utjsci@utq.edu.iq

\title{
Effects of Chrome Lignosulfonate Concentration and Temperature on Compressive Strength of Cement Class G Used in Oil Well Cementing
}

\author{
Jamal Harbi Al-Seedi \\ Department of Chemistry - College of Science \\ University of Thi-Qar
}

\section{Abstract:}

The primary function of Retarders in cement slurry design is to increase the thickening time to allow time for placement of the liquid slurry, The current study to observe the effects of temperature and different concentrations of the substance chrome lignosulfonate used as retarder (one on the additives)to cement class $\mathrm{G}$ used in cementing operation wells in oil fields southern Iraq on the compressive strength of the cement .The compressive strength of the samples concrete was measured by UCA equipment with different temperature depending on the depth and internal conditions of the well $\left(40 C^{-}, 60 C^{\circ}\right.$ and $80 C^{\circ}$ ), and pressuring affixed amount of $3000 \mathrm{psi}$.The experiments showed that the highest compressive strength was $1308 \mathrm{psi}, 3130 \mathrm{psi}, 3200 \mathrm{psi}$ of cement slurry where the concentration of chrome lignosulfonate $0.1 \%$ at temperature $40 \mathrm{C}^{\circ}, 60 \mathrm{C}^{\circ}, 80 \mathrm{C}^{\circ}$ respectively after a period of curing time 24 hours , while the less compressive strength within the study was $326 \mathrm{psi}, 412 \mathrm{psi}, 477 \mathrm{psi}$ of cement slurry where concentration of chrome lignosulfonate $0.5 \%$ after curing time 24 hours. The concrete increased as the temperature during the curing time increased within the range studied and decreasing compressive strength with addition a higher level of chrome lignosulfonate.

Key word: Compressive Strength, Chrome Lignosulfonate, Oil Well Cementing

\section{Introduction:}

Oil -well cementing is the process of mixing and placing cement slurry in the annulus between the casing string and the formation exposed to the drilled hole hardened cement isolates different zones within the well bore and supports the casing.

Oil well cement used in wells must have the required properties that apply for special field
condition.To day oil wells cover a wide range of depth and temperature condition than any time history (Abbaszadeh,2008).Therefore, the cement slurry compositions should be designed to encounter pressure to more than $30.000 \mathrm{psi}$ and temperature up to $700 \mathrm{~F}$ ( Nelson ,1990). The basic material of cement can be obtained from calcareous and argillaceous rocks such as limestone, clay, shale and slay .It may also contain sand, iron. (Satiyawira, et. al. 
2010).Cement usually consists of four major components

: Tricalcium Silicate $\left(\mathrm{C}_{3} \mathrm{~S}\right)$, Di calcium silicate $\left(\mathrm{C}_{2} \mathrm{~S}\right)$, Tri calcium aluminate $\left(\mathrm{C}_{3} \mathrm{~A}\right)$, and Tetra calcium aluminoferrite $\left(\mathrm{C}_{4} \mathrm{AF}\right)$.) where $\mathrm{C}=\mathrm{CaO}$ , $\mathrm{S}=\mathrm{SiO}_{2}, \mathrm{~A}=\mathrm{Al}_{2} \mathrm{O}_{3}, \mathrm{~F}=\mathrm{Fe}_{2} \mathrm{O}_{3} \quad$ (Rabia, 1985).The silicates, i.e. $\mathrm{C}_{3} \mathrm{~S}$ and $\mathrm{C}_{2} \mathrm{~S}$ are the most important compounds for the strength of hydrated cement paste(Mahdavi,2004).Glass G oil well cement is used as a basic well cement and, mixed with additives ,covers wide range of well depth and temperatures.(Kieffer and Rae,1987). The cement may not be compatible with complex geothermal well condition; therefore especial additive is required to improve the properties of the cement (Nelson, 1990; Ogbonna, 2009).

Retarder is a type of the additive that is able to slow down the cement hydration reactions. It is useful to allow cement slurry pumped in a longer time. Retarders are used to decrease the set time of cement slurries or to retard the cement setting (Erdogan, 1997). The most common retarders are natural lignin, calcium lignosulfonate and sodium lignosulfonate, chrome lignosulfonate and sugars (Satiyawira,et.al. 2010).Lignosulfonate or sulfonated lignin are water-soluble anionic polyelectrolyte polymers they are by production of wood pulp using sulfite pulping(Satiyawira,et. al. 2010).Lignosulfonate and salts have awide varity of applications. The single largest use for lignsulfonates is as plasticizers in making concrete, lignosulfonates are also used during the production of cement, where they act as grinding aids in the cement mill and as a raw mix slurry deflocculant (that reduces the viscosity of the slurry(Lebo, et. al. 2001).

The compressive strength is strength indication of the ability of set cement to provide zonal isolation, and to protect and support the casing string. In the oil and gas industry, two type of compressive strength for cement are defined .Early-age compressive strength is the compressive strength of cement at initial times after the preparation and placement of cement grout into the well bore and long -term compressive strength is the compressive strength of cement after completion of hydration process and exploitation of the well for several years of the well production operation .Development of high early -age compressive strength oil well cement is an important task in the oil well cement design(Di Lullo and Rae,2000).

The most widely used minimum strength required for any well bore operation is 500 psi in 24 hours at Bottom -hole static temperature. API specification requirement is a minimum of $500 \mathrm{psi}$ for 8 hours curing and 1000 psi for 24 hours curing period.(samsuri and seng,2000). The compressive strength is expressed as aultimate load attained (p)during the test over acrosssectional area(A)(Baez,2008).

\section{Materials and methods:}

\subsection{Materials:}

The materials used in this study were: API cement class $\mathrm{G}$ type Omani. The specific gravity of cement was 3.14, chrome lignosulfonate light brown powder (China), (R.O) fresh Water.

\subsection{Apparatus:}

Apparatus it is mainly consisted of compressive strength test Balance type ADAM, Constant speed blander model 20(ofite) (picture1-), Mud balance (ofite), ultra sonic cement analyzer (UCA) model 230 (ofite) (picture -2- ).

\subsection{Preparation of cement slurry samples.}

Ten different cement slurries $(\mathrm{A} \rightarrow \mathrm{J})$ were prepared and chosen to perform the analysis according to Table.1. 


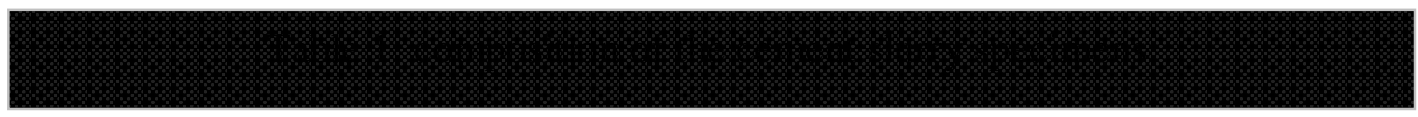

\begin{tabular}{|c|c|c|c|c|c|}
\hline $\begin{array}{c}\text { CEMENT } \\
\text { SLURRY } \\
\text { TYPE }\end{array}$ & $\begin{array}{c}\text { \%WEIGHT OF } \\
\text { CHROME } \\
\text { LIGNOSULFONATE } \\
\text { (BWOC } \%)\end{array}$ & $\begin{array}{c}\text { WEIGHT OF } \\
\text { CHROME } \\
\text { LIGNOSULFONAT } \\
\text { (GM) }\end{array}$ & $\begin{array}{l}\text { WEIGHT } \\
\text { OF } \\
\text { CEMENT } \\
\text { (GM) }\end{array}$ & $\begin{array}{l}\text { VOLUME } \\
\text { OF } \\
\text { WATER } \\
\text { (MI) }\end{array}$ & $\begin{array}{l}\text { DENSITY } \\
\text { OF } \\
\text { SLURRY } \\
\text { (GM/ML) }\end{array}$ \\
\hline $\mathrm{A}$ & 0.00 & 0.00 & 1000 & 440 & 1.9 \\
\hline B & 0.10 & 1.00 & 1000 & 440 & 1.9 \\
\hline $\mathrm{C}$ & 0.15 & 1.50 & 1000 & 440 & 1.9 \\
\hline D & 0.20 & 2.00 & 1000 & 440 & 1.9 \\
\hline $\mathrm{E}$ & 0.25 & 2.50 & 1000 & 440 & 1.9 \\
\hline $\mathrm{F}$ & 0.30 & 3.00 & 1000 & 440 & 1.9 \\
\hline $\mathrm{G}$ & 0.35 & 3.50 & 1000 & 440 & 1.9 \\
\hline $\mathrm{H}$ & 0.40 & 4.00 & 1000 & 440 & 1.9 \\
\hline I & 0.45 & 4.50 & 1000 & 440 & 1.9 \\
\hline $\mathrm{J}$ & 0.50 & 5.00 & 1000 & 440 & 1.9 \\
\hline
\end{tabular}

Dry materials are weighed and then uniformly blended before being added to the mixing fluids .The blender motor is turned on, the mixer is operated at 4.000RPM for 15 seconds, followed by 35 seconds at 12.000RPM (API, 1991).

\subsection{Determination of Slurry Density:}

Cement slurry density determined by mud balance (API, 1991).

\subsection{Compressive Strength Test:}

Compressive strength test to any samples taken in table (1) by ultra sonic cement analyzer equipment under pressure 3000 psi at several temperatures $1-40 \mathrm{C}^{\circ} 2-60 \mathrm{C}^{\circ} 3-80 \mathrm{C}^{\circ}$. (Instruction manual.UCA, 2007; API 1997).

\section{RESULTS AND DISCUSSION:}

Where examined compressive strength using all sample cement prepared according to Table (1) at different temperatures at bottom hole static
temperature(BHST) and curing time periods ,8 hours , 12 hours and 24 hours, by using pressing affixed amount 3000 PSI , and Tables 2,3 and 4 show that.

The results after 8 hours curing time were the cement slurry type( B )where the concentration of chrome lignosulfonate $0.1 \%$ has higher compressive strength in temperature $40 \mathrm{C}^{\circ}$, also cement slurry type (B) had the highest compressive strength at temperature $60 \mathrm{C}^{\circ}$ and 80 $\mathrm{C}^{\circ}$.while cement slurry type $(\mathrm{J})$ which have a concentration of chrome lignosulfonate where $0.5 \%$ less compressive strength and for each grad heat in the research, table (2) and Figure(1)shows that.

The compressive strength of the cement slurry were also measured the same after 12 hours curing time, under the pressure 3000 PSI and table (3) shows the results so that the highest compressive strength extent of $40 \mathrm{C}^{\circ}$ was the sample cement slurry type (B) possessed the 
highest compressive strength of stiffness in $60 \mathrm{C}^{\circ}$ and $80 \mathrm{C}^{\circ}$. while cement slurry sample type $(\mathrm{J})$ was less compressive strength in all grades 40 $\mathrm{C}^{\circ}, 60 \mathrm{C}^{\circ}$ and $80 \mathrm{C}^{\circ}$, and figure (2)illustrates this . Table (4) represents the results of compressive strength after 24 hours curing time, was found that the cement slurry type( B) where the focus concentration chrome lignosulfonate $0.1 \%$ had the highest compressive strength at temperature $40 \mathrm{C}^{\circ}$ and also the cement slurry type( B) when temperature $60 \mathrm{C}^{\circ}$ and $80 \mathrm{C}^{\circ}$ possessed the highest compressive strength stiffness. The sample type( $\mathrm{J}$ )was less compressive strength all grades thermal and figure(3) shows the results.

Table 2: Compressive strength at 8-hour

\begin{tabular}{|c|c|c|c||}
\hline \multirow{2}{*}{$\begin{array}{c}\text { CEMENT SLURRY } \\
\text { TYPE }\end{array}$} & \multicolumn{3}{|c||}{ COMPRESSIVE STRENGTH } \\
\cline { 2 - 4 } & $\mathrm{T}=40 \mathrm{C}^{\circ}$ & $\mathrm{T}=60 \mathrm{C}^{\circ}$ & $\mathrm{T}=80 \mathrm{C}^{\circ}$ \\
\hline $\mathbf{A}$ & 684 & 961 & 890 \\
\hline $\mathbf{B}$ & 979 & 1373 & 1417 \\
\hline $\mathbf{C}$ & 912 & 1282 & 1325 \\
\hline $\mathbf{D}$ & 601 & 1072 & 1286 \\
\hline $\mathbf{E}$ & 400 & 549 & 872 \\
\hline F & 326 & 690 & 779 \\
\hline G & 306 & 628 & 663 \\
\hline $\mathbf{H}$ & 393 & 423 & 552 \\
\hline I & 211 & 316 & 381 \\
\hline J & 200 & 256 & 309 \\
\hline
\end{tabular}

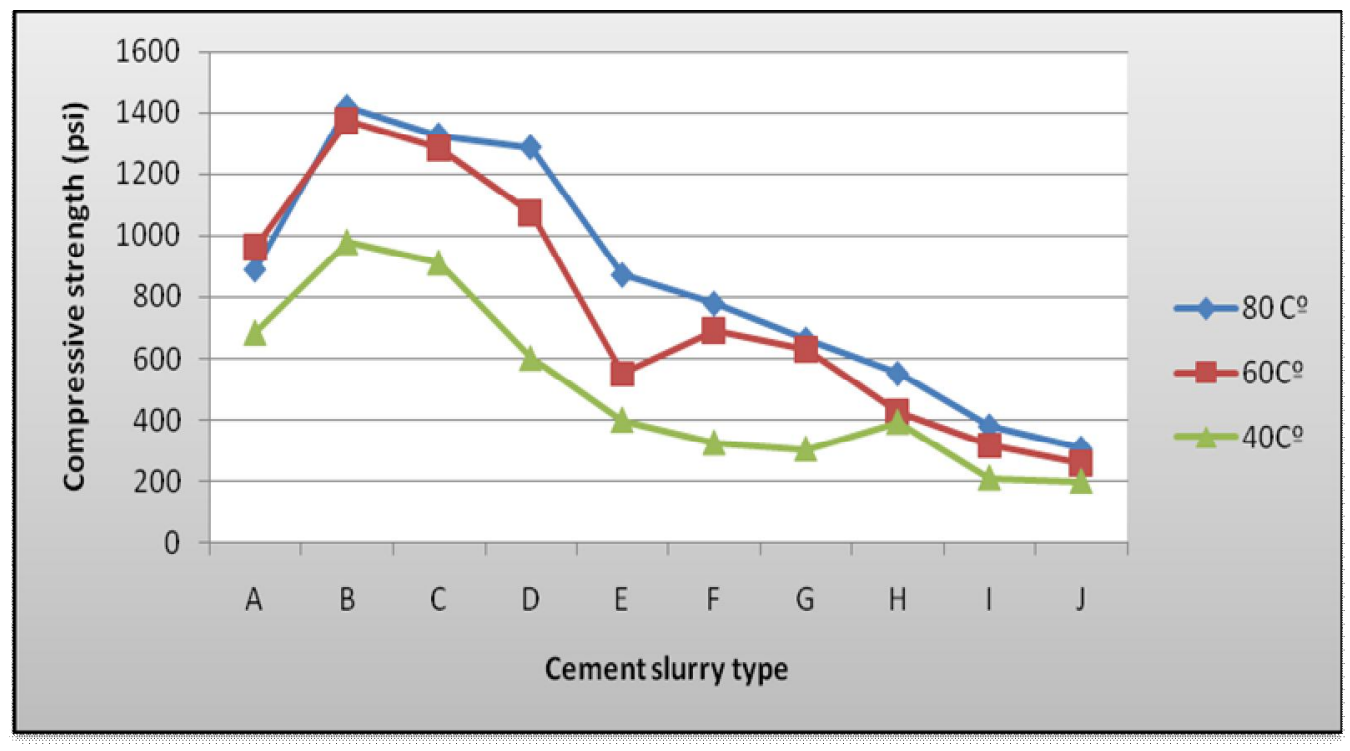

Figure (1) Compressive strength at $8 \mathrm{hrs}$ 
Table 3: Compressive strength at 12-hour

\begin{tabular}{|c|c|c|c||}
\hline \multirow{2}{*}{$\begin{array}{c}\text { CEMENT SLURRY } \\
\text { TYPE }\end{array}$} & \multicolumn{3}{|c||}{ COMPRESSIVE STRENGTH } \\
\cline { 2 - 4 } & $\mathrm{T}=40 \mathbf{C}^{\circ}$ & $\mathrm{T}=60 \mathbf{C}^{\circ}$ & $\mathrm{T}=80 \mathrm{C}^{\circ}$ \\
\hline $\mathbf{A}$ & 1235 & 1568 & 1652 \\
\hline $\mathbf{B}$ & 1708 & 2277 & 2624 \\
\hline $\mathbf{C}$ & 1421 & 2240 & 2509 \\
\hline $\mathbf{D}$ & 887 & 1892 & 2310 \\
\hline $\mathbf{E}$ & 575 & 724 & 1100 \\
\hline $\mathbf{F}$ & 555 & 700 & 984 \\
\hline $\mathbf{G}$ & 490 & 692 & 720 \\
\hline $\mathbf{H}$ & 421 & 456 & 559 \\
\hline $\mathbf{I}$ & 339 & 399 & 470 \\
\hline $\mathbf{J}$ & 287 & 382 & 432 \\
\hline
\end{tabular}

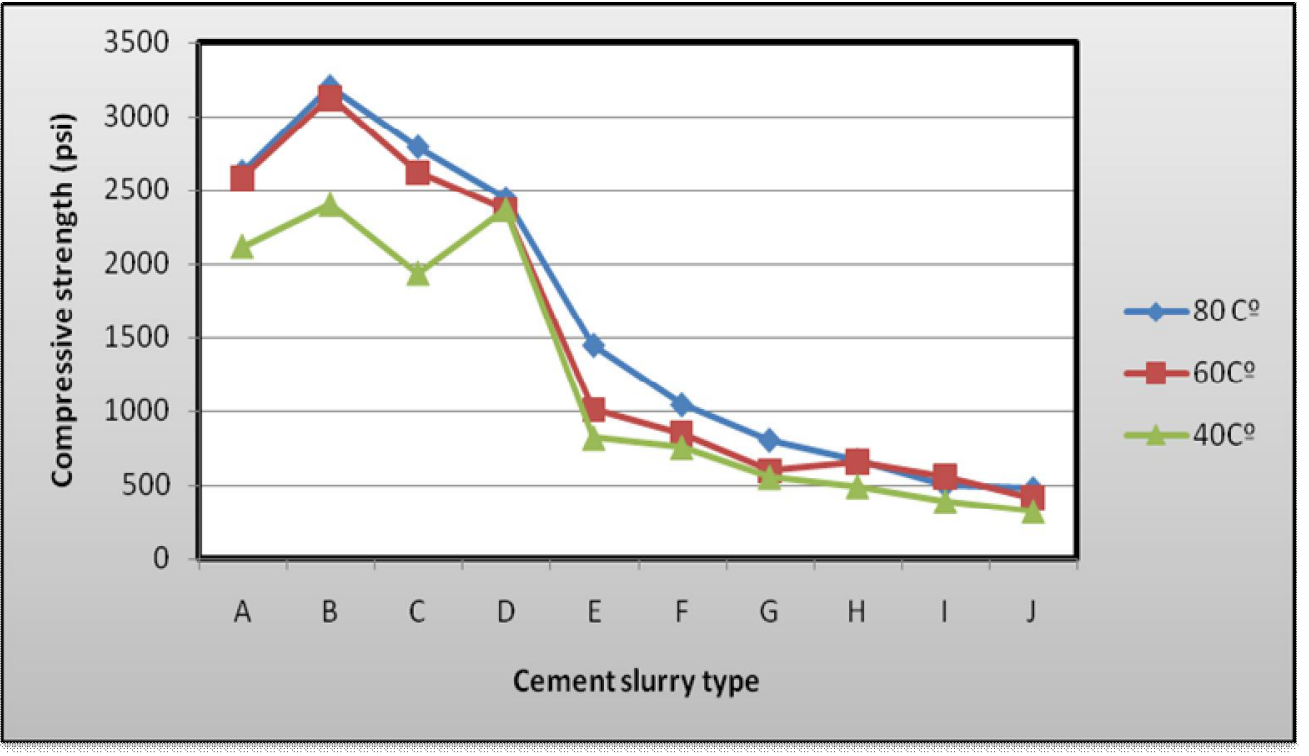

Figure (2) Compressive strength at $12 \mathrm{hrs}$ 
Table 4: Compressive strength at 24-hour

\begin{tabular}{||c|c|c|c||}
\hline \multirow{2}{*}{$\begin{array}{c}\text { CEMENT SLURRY } \\
\text { TYPE }\end{array}$} & \multicolumn{3}{|c|}{ COMPRESSIVE STRENGTH } \\
\cline { 2 - 4 } & $\mathrm{T}=40 \mathrm{C}^{\circ}$ & $\mathrm{T}=60 \mathrm{C}^{\circ}$ & $\mathrm{T}=80 \mathrm{C}^{\circ}$ \\
\hline A & 2117 & 2584 & 2623 \\
\hline B & 2400 & 3130 & 3200 \\
\hline C & 1937 & 2624 & 2790 \\
\hline E & 2365 & 2365 & 2440 \\
\hline F & 820 & 1007 & 1445 \\
\hline G & 758 & 846 & 1040 \\
\hline H & 558 & 596 & 802 \\
\hline I & 497 & 657 & 669 \\
\hline J & 393 & 560 & 500 \\
\hline
\end{tabular}

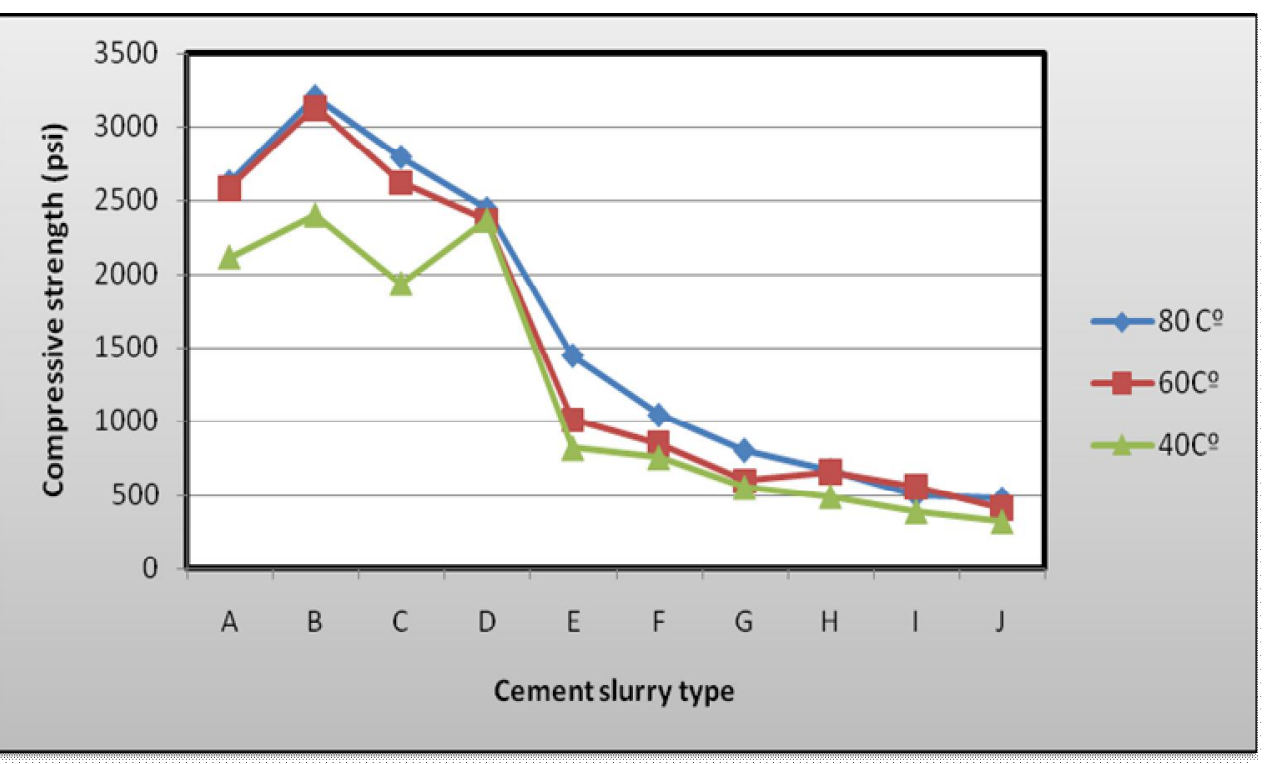

Figure (3) Compressive strength at $24 \mathrm{hrs}$ 
From tables 2,3and 4 ,and Figures 1,2,3.test results indicated that low concentration of chrome lignosulfonate (retarder) increase compressive strength, higher concentrations values of chrome lignosulfonate (retarder) are affected compressive strength at $8 \mathrm{hrs}, 12 \mathrm{hrs}$ and $24 \mathrm{hrs}$. Increasing retarder concentration not only resulted to increase in thickening time ,but a decrease in both rheological properties and earlycompressive strength development as well as increase in free fluid results (Ogbonna,2009). That effect of $\%$ weight of lignosulfonate and temperature on the compressive strength of the specimens and maximum compressive strength is reached if $0.1 \%$ weight of lignosulfonate added in the cement slurry. Our results also showed that the compressive strength increases with increasing temperature and increasing curing time.

Also studied (L abibzada ,M .et. al. ,2010) showed that compressive strength of the proposed cement after 48 curing hours is increased approximately up to 150percent in comparison to the corresponding value after 24 curing time under ambient pressure and temperature .lignosulfonate is the best performance decreasing viscosity to improve fluidity and setting time longer period than the other, but the result of the compressive strength is weakest .Calcium lingosulfonate is the best performance in compressive strength, but poor result in the viscosity and setting time(Trithos and Toemsak,2010). Some of the scientists have been studied the water and additives effect on cement mechanical properties without considering the effect of pressure or temperature inside the well bore (Dahab and Omar, 1989).some of the others add the effect of temperature factor in their studies .for example in 1999, Noik and Rivereau compared behavior of four various compounds of cement class $\mathrm{G}$ at $120 \mathrm{C}^{\circ}, 140 \mathrm{C}^{\circ}$ and $180 \mathrm{C}^{\circ}$ their target was the evaluation of silica sand effects on cement slurry. As some of the results of the study coincided with the current study was conducted by researchers (Samsuri and Seug, 2000).

\section{Conclusions and recommend:}

The current study showed that the compressive strength of cement concrete increased as temperature increased during a curing time If the temperature was kept constant, the compressive strength tended to increase as the curing time increased .The compressive strength of cement concrete increased was increasing within the range of temperature and curing time studied.

The compressive strength of concrete increased due to an addition of the chrome lignosulfonate .It reached a maximum value at the addition of chrome lignosulfonate $0.1 \%$ of the cement weight at various temperatures. The addition of chrome lignosulfonate at higher level resulted in a decrease in the compressive strength of the cement

\section{References:}

Abbaszadeh, M. (2008).Detection and Modeling Cement Failure in High Pressure/High Temperature Wells, Using Finite Element Method .M.SC.thesis ,A\&M University,Taxas ,U.S.A.

American Petroleum Institute (API). (1991).Specification for Material and Testing Well Cements.API,1220 L Street ,Northwest, Washington DC,USA.

American Petroleum Institute (API). (1997).Recommended Practice for Testing Well Cement-10.22 $2^{\text {nd }} E d .$, December.

Baez,J.R.P.(2008).Tensile Strength of Shrinkage Compensating Concrete with Fly Ash,Master Thesis ,University of Puerto Rico, Mayaguez.

Dahab, A.S.,and Omar,A.E.(1989).Rheology and Stability of Saudi Cement for Oil Well Cementing .Journal.King Saud Unviersity.,Riyadh,Eng.Sci,:(1,2):273-286.

Di Lullo,G.,and Rae,Ph.(2000).Cement for Long Term Isolation -Design Optimization by Computer Modelling and Prediction .Paper IADCISPE 62745.Asia PacificDrilling Technology, Kuala Lumpur ,Malaysia,11-13.

Erdogan, T.Y. (1997).Admixtures for concrete, Middle East Technical University AnkaraTurkey.Vol.4, No, 9, 
Instruction Manual.Ultrasonic Cement Analyzer (2007).OFI Testing Equipment Inc., Houston Texas, U.S.A.

Kamsuwan,T.,and Srikhirin,T,(2010).Effect of lignosulfonate on mechanical and setting time properties of geopolymer paste.Department of civil engineering, Siam University. Bongkok, Thailand.

Kieffer,P.Rae.(1987),How Gelation Affects Oil Well Cements,Petroleum Engineer International,May46.

Labibzadeh,M,Zahabizadeh,B,.Khajehdezfuly,A. (2010).Early -age compressive strength assessment of oil well class $G$ cement due to bore hole pressure and temperature changes.Journal of American Science:6(7).

Lebo,S.E,;Gargulak,J.D;and McNally,T.J.(2001). kirk-Othmer Encyclopedia of Chemical Technology.

Mahdavi,F.(2004).Drying Shrinkage of Cement Pastes and High Strength Concretes,Master thesis ,San Jose State University.

Nelson,E.B.(1990).Well Cementing $\quad .2^{\text {nd }}$ edition ,Schlumberger Educational Services ,Houston,Texas.pp.9-14.

Noik,Ch.,and Rivereau ,A.(1999).Oil well Cement Durability.paper SPE 56538 Presented at the Annual Technical Conference and Exhibition ,Houston ,Texas:3-6.

Ogbonna ,F.J.(2009).The secondary effects of lignosulfonate cement retarder on cement slurry properties.ARPN Journal of Engineering and Applied Sciences .Vol.4,NO.9.

Rabia,H.(1985).Oil Well Drilling Engineering :Principles and Practice ,Graham and Trotman .Inc.,London.

Ramachandran,V.S.(2000).Effect of retarders /water Reducers on slump loss in superplasticized concrete.DBR Paper NO.10:3.Super plasticizers American Concrete Institute special publication.68,P.393-407.

Samsuri,A ; Seng ,Y.B.(2000).Improved plam oil fly ash is abetter oil well cement additives.malaysian Science \&Technology Congress.University Teknologi Malaysia ,Research Managament center.81310Skudai.JohorBahru.

Satiyawira,B;Fathaddin ,M.T and Setiawan, R,(2010). Setiawan,R,(2010).Effects of Lignosulfonate and Temperature on
Compressive strength of Cement .Proceedings World Geothermal Congress.Bali, Indonesia .

Nomenclature:

API = American Petroleum Institute

BHST $=$ Bottom Hole Static Temperature

\%BWOC $=$ Percentage by weight of cement

GM = Gram

Ofite = Ofi Testing equipment

$\mathbf{T}=$ Temperature

UCA = Ultra sonic Cement Analyzer equipment

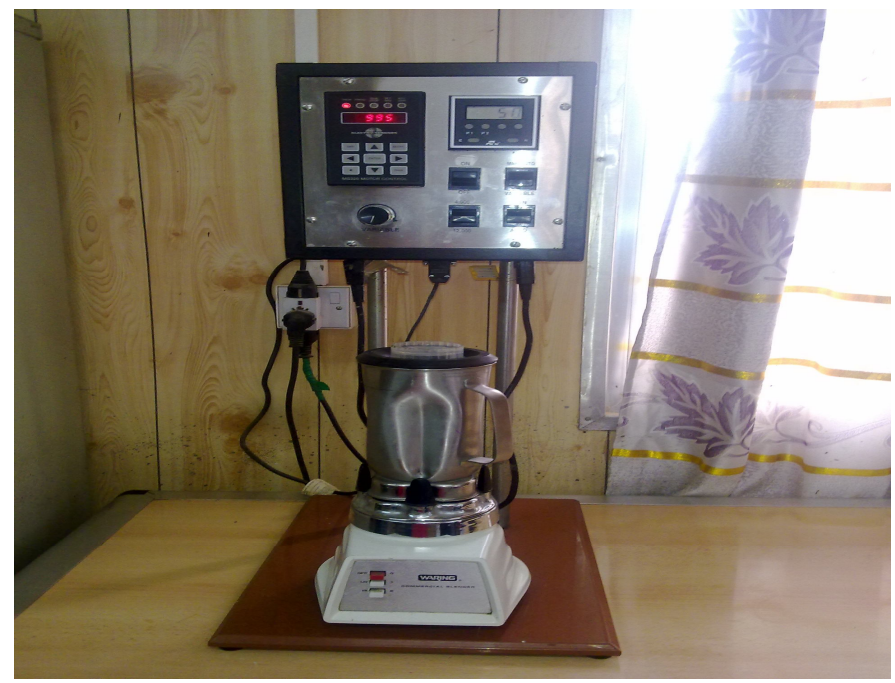

Picture -1- Constant speed blander

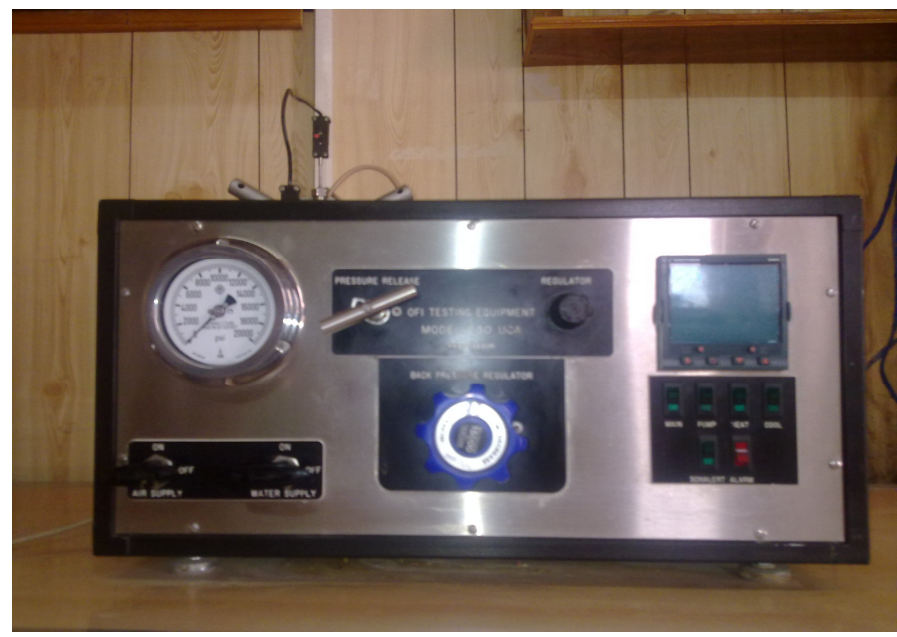

Picture -2- UCA equipment 
تأثيرات تركيز Chrome Lignosulfonate ودرجة الحرارة على قوة تصلب الأسمنت صنف Gستخدم في تسميت الآبار النفطية

\author{
جمال حربي حسين السعيدي \\ قسم الكيمياء - كلية العلوم - جامعة ذي قار
}

الخلاصة: والاحة سائل الأسمنت داخل البئر ضمن الشروط الداخلية من درجة حرارة وضغط.لذلك تخصصت الدراسة الحالية لملاحظة تأثثرات

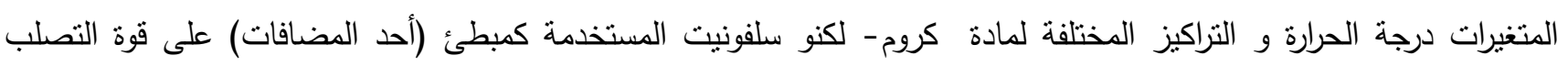
للسمنت صنف G المستخدم في نسميت الآبار النفطية في حقول جنوب العراق. حيث نم قياس قوة التصلب مختبريا" لجميع الخلطات الأسمنتية المحضرة بإضافة تراكيز مختلفة من مادة كروم لكنوسلفونيت بواسطة جهاز (UCA) وبدرجات حرارة مختلفة

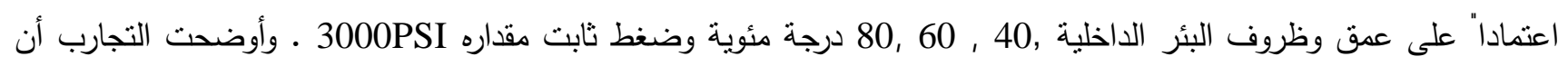
أعلى قوة نصلب كانت 3200psi 3130psi, 1308 psi للخلطة الأسمنتية التي نزكيز كروم لكنوسلفونيت

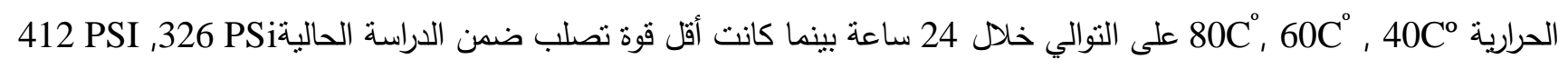
477 PSI ,

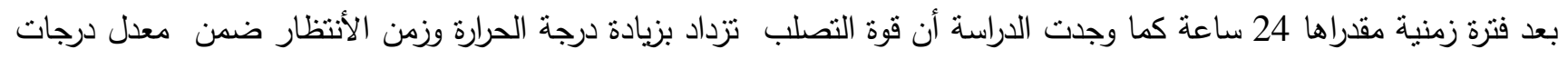
الحرارة والزمن في هذة الدراسة ـ كما أوضحت الدراسة نقصان قوة التصلب بصورة ملحوظة عند إضافة تراكيز عالية من مادة كروم لكنوسلفونيت. 